Pesq. Vet. Bras. 36(4):258-262, abril 2016

DOI: $10.1590 / \mathrm{S} 0100-736 \mathrm{X} 2016000400002$

\title{
Influence of scrotal bipartition on spermatogenesis yield and sertoli cell efficiency in sheep ${ }^{1}$
}

\begin{abstract}
Ramon T.G.A. Rodrigues ${ }^{2}$, José R.S. Santos ${ }^{2}$, Lilianne M.S. Azerêdo ${ }^{2}$, Ediane F. Rocha², Maria A.M. Carvalho ${ }^{3}$, Maria J.I.D. Portal ${ }^{4}$, Otávio B. Sousa ${ }^{2}$ and Danilo J.A. Menezes ${ }^{2 *}$

ABSTRACT.- Rodrigues R.T.G.A., Santos J.R.S., Azerêdo L.M.S., Rocha E.F., Carvalho M.A.M., Portal M.J.I.D., Sousa O. B. \& Menezes D.J.A. 2016. Influence of scrotal bipartition on spermatogenesis yield and Sertoli cell efficiency in sheep. Pesquisa Veterinária Brasileira 36(4):258-262. Unidade Acadêmica de Medicina Veterinária, Centro de Saúde e Tecnologia Rural, Universidade Federal de Campina Grande, Avenida Universitária s/n, Santa Cecília, Patos, PB 58708-110, Brazil. E-mail: mdanayres@gmail.com

With the objective to assess the effect of scrotal bipartition on spermatogenesis in sheep, the testes were used from 12 crossbred rams of sheep farms in the municipality of Patos, Paraíba, Brazil, distributed into two groups: GI with six rams with scrotal bipartition, and GII with six rams without scrotal bipartition. The testicular biometry was measured and the testes were collected, fixed in Bouin and fragments were processed to obtain histological slides. The spermatogenesis yield and the Sertoli cell efficiency was estimated by counting the cells of the spermatogenetic line at stage one of the seminiferous epithelium cycle and the Sertoli cells. The results were submitted to analysis of variance with the ASSISTAT v.7.6 program and the mean values were compared by the Student-Newman-Keuls test (SNK) at 5\% significance. The testicular biometric parameters did not show statistical difference $(p>0.05)$ between the groups. The meiotic, spermatogenetic and Sertoli cell efficiency were higher in bipartitioned rams $(\mathrm{p}<0.05)$, while the mitotic yield did not differ $(p>0.05)$ between GI and GII. The results indicated that there is superiority in the spermatogenetic parameters of bi-partitioned rams, suggesting that these sheep present, as reported in goats, indication of better reproductive indices.
\end{abstract}

INDEX TERMS: Scrotal bipartition, spermatogenesis yield, Sertoli cells, reproduction, testicle, sheep.

RESUMO-- [Influência da bipartição escrotal sobre o rendimento da espermatogênese e eficiência das células de Sertoli em ovinos.] Com o objetivo de avaliar o efeito da bipartição escrotal sobre a espermatogênese em ovinos, foram utilizados os testículos de 12 ovinos sem raça definida oriundos de criadouros do município de Patos-PB, Brasil, distribuídos em dois grupos, GI de seis animais com

\footnotetext{
${ }^{1}$ Received on December 1, 2015.

Accepted for publication on January 15, 2016.

${ }^{2}$ Unidade Acadêmica de Medicina Veterinária, Centro de Saúde e Tecnologia Rural (CSTR), Universidade Federal de Campina Grande (UFCG), Avenida Universitária s/n, Santa Cecília, Patos, PB 58708-110, Brazil. *Coresponding author: mdanayres@gmail.com

${ }^{3}$ Departamento de Morfofisiologia Veterinária, Centro de Ciências Agrárias, Universidade Federal do Piauí (UFPI), Campus Ministro Petrônio Portela, Socopo, Teresina, PI 64049-550, Brazil.

${ }^{4}$ Departamento de Fisiologia Animal, Facultad de Veterinária, Universidad Complutense de Madrid, Avda. Puerta de Hierro, s/n, Ciudad Universitaria, 28040, Madrid, Spain.
}

bipartição escrotal e o GII de seis animais sem bipartição escrotal. Realizou-se a aferição da biometria testicular, em seguida, os testículos foram coletados, fixados em Bouin e fragmentos foram processados para obtenção de lâminas histológicas. Foi estimado o rendimento da espermatogênese e eficiência das células de Sertoli contando-se as células da linhagem espermatogênica no estádio I do Ciclo do Epitélio Seminífero, bem como as células de Sertoli. Os resultados foram submetidos à análise de variância pelo programa ASSISTAT v.7.6 e os valores médios foram comparados pelo teste Student-Newman-Keuls (SNK) a 5\% de significância. Os parâmetros de biometria testicular não apresentaram diferença estatística $(p>0,05)$ entre os grupos. Os rendimentos meiótico, espermatogênico e a eficiência das células de Sertoli mostraram-se superiores em animais bipartidos $(\mathrm{p}<0,05)$, enquanto o rendimento mitótico não diferiu $(p>0,05)$ entre GI e GII. Os resultados indicaram existir superioridade nos parâmetros espermatogênicos de ovinos bipartidos, sugerindo que estes animais apre- 
sentam, assim como constatado em caprinos, indicativo de melhores índices reprodutivos.

TERMOS DE INDEXAÇÃO: Bipartição escrotal, espermatogênese, células de Sertoli, ovinos, reprodução, morfologia, testículo, ovinos.

\section{INTRODUCTION}

Understanding the physiology of domestic animals is essential for stock rearing with high productivity indexes. The physiological parameters include the reproductive mechanisms, especially the gonadal dynamic, an important factor in reproductive plasticity that acts integrated with the environment and climate and the relationship between its genotype and the environment is very important for reproduction of the species (Santos et al. 1998).

Successive reproduction of a herd depends, among other factors, on the choice of a good breeder that will transmit its genetic characteristics to its future descendants. Among the factors to be assessed in the male, the morphological aspects are important phenotypic indicators of what is needed to obtain in future offspring. In addition to the body confirmation, the morphology of the reproductive apparatus should be considered in this choice.

In regions with tropical climate, some manifestations have been reported of morphological alterations of the reproductive organs in goats, such as the appearance of a division in the scrotum of these animals (Robertshaw 1982, Nunes et al. 1983). The characteristics of scrotal bipartition have also been reported in sheep of the Morada Nova breed (Melo 2013). In the semiarid region of the state of Paraíba, Brazil, sheep raisers have also reported the appearance of rams with these characteristics within their herds.

These and other morphological alterations are due to the evolution of the species, that is characterized by changes in the frequency of the occurrence of determined genes in response to factors including mutation, natural selection, geographic or reproductive isolation and climatic adversities. Thus the situations of certain genes that until then were quiescent in the organism, may be activated, triggering the appearance of morphological adaptations in the animals (Linhares \& Gewandsznajder 2000).

To analyze the effect of morphological alterations in the reproductive organs on reproductive efficiency, it is necessary to observe the testicular plasticity, especially regarding spermatogenesis, , that can indicate the reproductive efficiency of the animal submitted to intrinsic or extrinsic influences. In this way, testicle histological quantification becomes an efficient instrument to determine the spermatogenetic capacity of an animal in the face of physiological or pathological conditions (Castro et al. 1997, Leal 2004).

Acquisition of knowledge regarding the influence of scrotal bipartition on reproductive efficiency in sheep has become relevant and necessary, considering that in the goats a positive correlation has already been found between these two factors. Thus the objective of the present study was to identify the presence and intensity of differences in the spermatogenesis process in animals with bipartitioned scrotum, by a histological study associating the morphological characteristics of animals from the semiarid region of
Paraíba state, Brazil. The results of this study may help sheep rearers to select rams with high reproductive capacity to enhance the performance of their production activities.

\section{MATERIALS AND METHODS}

Location and research animals. The testis were collected from 12 hair crossbred rams, approximately 1-year-old, identified by observing the change in the hoof wall (Silva 2001) and homogeneous body score (mean weight $31.5 \mathrm{~kg}$ ). The animals came from extensive rearing systems on rural properties in the municipality of Patos, PB, Brasil, reared under the same food and climatic conditions. The animals were divided into two groups, considering the scrotal conformation, as proposed by Almeida (2003) for goats, following the classification by Nunes et al. (1983). Group 1 (GI) consisted of six animals with a $10 \%$ of division in the distal portion of the scrotum and were considered animals with scrotal bipartition, and group two (GII) consisted of six animals without scrotal bipartition.

Testicular biometry. Before slaughtering the animals, the testes were measured, pulling them down and backwards to take the measurements of the scrotal perimeter using a tape measure at the widest part of the scrotum (mid portion).

After slaughtering the animals, the testes were carefully collected with a cutting instrument, dissected from the scrotum and separated from the epididymis, weighed on $0.01 \mathrm{~g}$ precision digital scales and then the testes diameter and length were measured with $0.05 \mathrm{~mm}$ precision.

Histological processing. The testes were sectioned in cross cuts approximately $5 \mathrm{~mm}$ thick, and five cuts were separated from the capitate region, five from the middle region and five from the caudal region of the organ. The cuts were submersed in Bouin solution for fixing for 24 hours, washed in $70 \%$ alcohol and kept in the solution. The cuts were then processed in a conventional histological routine with impregnation in paraffin to obtain $5 \mu \mathrm{m}$ thick cuts by microtomy. The sections were stained using the hematoxylin-eosin (HE). The material was analyzed under a light microscope (Olympus BX40) by an image analysis system (Image Pro-Express v.6.0), images were taken of the seminiferous tubes and the nuclear diameters were measured in ten cells of each cell type analyzed in each testicle and the nuclear diameter of the Sertoli cells to obtain the Mean Nuclear Diameter (ND).

Counting the cell types of the seminiferous tubes. A total of 72 histological slides were analyzed (three slides of each testicle, six slides per animal), in which stage one of the Seminiferous Epithelium Cycle (CES) was identified by the tubular morphology method (Cardoso 1981, Ortavante, Courot \& Hochereau-de-Reviers, 1984), observing the alterations in the shape of the spermatid nucleus, the occurrence of meiotic division and spermatid position in the seminiferous epithelium. The different cell types were counted in the 20 most circular cross cuts from seminiferous tubes per testicle. The CES cells counted were type A spermatogonia, young spermatocyte I in the pre-leptotene or leptotene phase, old spermatocyte I at the pachytene phase and rounded spermatocytes,in addition to the Sertoli cells that were counted based on the presence of their nucleoles, due to the enormous variation and difficulty in delimiting the cell nucleus.

All the cell numbers found were corrected according to the Abercrombie correlation factor (Abercrombie, 1946) modified by Amann \& Almquist (1962), for the nuclear diameter and cut thickness represented by the formula: number corrected $=$ count obtained $x$ cut thickness/cut thickness $+\sqrt{(N D / 2)^{2}-(N D / 4)^{2}}$.

Yield calculation. The spermatogenetic yield and Sertoli cell efficiency were estimated by counting the cell population of 20 cross sections of seminiferous tubes, involving the following indices: 
Mitosis yield or coefficient of efficiency: calculated by the ratios between primary spermatocytes in pre-leptotene/leptotene at stage I and spermatogonia at stage I;

General spermatogenesis yield: calculated from the ratio between rounded spermatid and spermatogonia at stage I;

Sertoli cell efficiency: calculated from the ratio between the total number of rounded spermatids in stage I and the total number of Sertoli cells.

Statistical analysis. The statistical analysis was made by a completely randomized design (two treatments and six replications).The results obtained were submitted to analysis of variance by the ASSISTAT v.7.6 statistical program and the mean values were compared by the Student-Newman-Keuls test (SNK) to compare the means at $5 \%$ significance.

\section{RESULTS AND DISCUSSION}

In the rams used in the present study, only one degree of scrotal bipartition was observed that was less than $50 \%$, ie $10 \%$ of the scrotum length (Figure 1), similar to other studies on sheep (Oliveira \& Menezes 2012, Tolentino 2012), but differing from research on goats, in which animals were also identified with degrees of scrotal bipartition greater than $50 \%$ of the total scrotum length (Nunes et al. 1983, Nunes 2005, Almeida et al. 2008, Almeida et al. 2010).

The analysis of the scrotum testicle biometric data did not show significant statistical difference among the two groups of animals (Table 1).

The scrotum circumference and testicle length means observed in the present study (Table 1), compared with those observed in goats, were similar to those found by Almeida et al. (2010) but lower than those found by Vilar Filho et al. (1993) and greater than those reported by Oliveira et al. (2002). This variation among the testes of the sheep studied from that of the goats observed in the literature was probably due to differences in the standard age during the study or even to the peculiar variation among the crossbred goats in the different studies. However, the importance is highlighted of scrotum circumference analysis to assess sheep, because it was shown by animals of the Santa Inês breed that this parameter can help select animals with high weight gain and reproductive potential, and significant correlation has been observed between the scrotum circumference and the body weight of these animals (Bittencourt, Ribeiro Filho \& Almeida 2003), unlike what has been reported in a study with buffaloes, that wasn't shown correlation between these parameters (da Luz et al. 2013).

The mean testicle weight values of Santa Ines sheep, that ranged from 80 to $85.07 \mathrm{~g}$ (Table 1), were compatible with the findings by Siddiqui et al. 2005 in Pakistani sheep of the Kajli breed, approximately 12 months old. In contrast, these numbers were lower than those found in a study with Santa Ines sheep (Martins 2006), because they were older animals than those used in the present study.

Biometric parameters are practical, cost free measurements and can be used as a means to classify puberty in sheep by any farmer who wishes to improve the genetics of his herd (Oliveira 2002), because the highest testicle growth rates occur at this phase, when the primary spermatocytes appear and the seminiferous tubes elongate (Hafez \& Hafez 2004). Studies have shown that goats with the scrotal bipartition characteristic have greater bodyweight, showing benefits for the production of these animals (Almeida et al. 2010).

Measurements such as scrotum perimeter, testicle length and weight are associated to the capacity of the organ

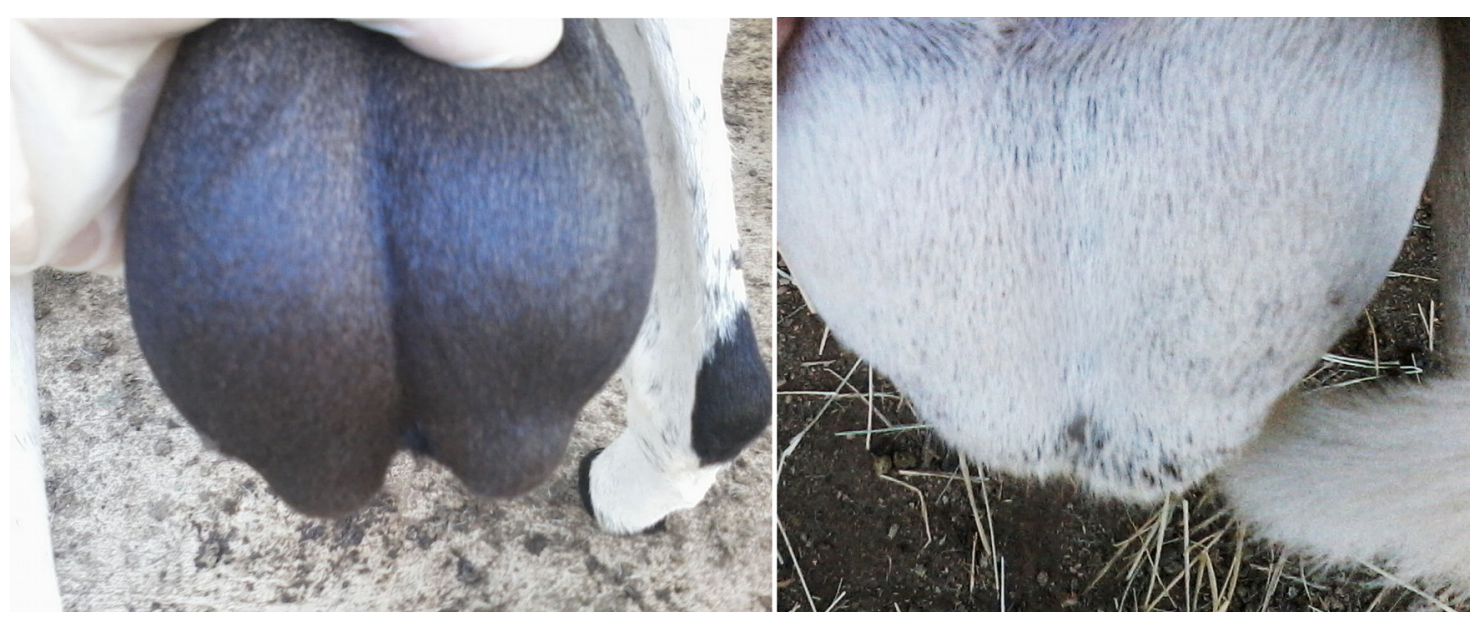

Fig.1. Scrotum of crossbred rams. On left, sheep with scrotal bipartition (GI), and the right one without scrotal bipartition (GII).

Table 1. Scrotum testicle biometric values (mean \pm standard deviation) of groups of crossbred sheep studied. Patos, PB, Brazil 2014

\begin{tabular}{|c|c|c|c|c|c|c|c|}
\hline \multirow[t]{2}{*}{ Group } & \multicolumn{2}{|c|}{ Length $(\mathrm{cm})$} & \multicolumn{2}{|c|}{ Diameter $(\mathrm{cm})$} & \multicolumn{2}{|c|}{ Weight (g) } & \multirow[t]{2}{*}{ Scrotal circumference $(\mathrm{cm})$} \\
\hline & Right & Left & Right & Left & Right & Left & \\
\hline GI & $6.79 \pm 0.14^{\mathrm{a}}$ & $6.34 \pm 0.36^{\mathrm{a}}$ & $4.92 \pm 0.19^{\mathrm{a}}$ & $4.92 \pm 0.26^{\mathrm{a}}$ & $85.07 \pm 14.06^{\mathrm{a}}$ & $81.57 \pm 15.79^{a}$ & $25.33 \pm 1.21^{\mathrm{a}}$ \\
\hline GII & $6.72 \pm 0.28^{\mathrm{a}}$ & $6.39 \pm 0.17^{\mathrm{a}}$ & $4.83 \pm 0.17^{\mathrm{a}}$ & $4.83 \pm 0.17^{\mathrm{a}}$ & $84.44 \pm 19.15^{\mathrm{a}}$ & $80.01 \pm 24.25^{\mathrm{a}}$ & $25.16 \pm 1.94^{\mathrm{a}}$ \\
\hline
\end{tabular}

GI: Group I (bipartitioned); GII: Group II (not bipartitioned); Right; Left. Means followed by the same letter in the same colu$\mathrm{mn}$ to not differ statistically by the SNK test at $5 \%$ de significance $(\mathrm{P}>0.05)$. 
Table 2. Mitotic, meiotic, spermatogenic and Sertoli cell efficiency of the seminiferous epitheliumin Santa Ines sheep (mean \pm standard deviation)

\begin{tabular}{lcccc}
\hline Group & $\begin{array}{c}\text { Mitotic } \\
\text { Income }\end{array}$ & $\begin{array}{c}\text { Meiotic } \\
\text { Income }\end{array}$ & $\begin{array}{c}\text { Income } \\
\text { Spermatogenic }\end{array}$ & $\begin{array}{c}\text { Efficiency of } \\
\text { Sertoli cells }\end{array}$ \\
\hline GI & $1.90 \pm 0.15^{\mathrm{a}}$ & $27.20 \pm 6.08^{\mathrm{a}}$ & $51.61 \pm 11.17^{\mathrm{a}}$ & $22.74 \pm 7.29^{\mathrm{a}}$ \\
GII & $1.78 \pm 0.30^{\mathrm{a}}$ & $19.37 \pm 2.86^{\mathrm{b}}$ & $34.33 \pm 6.31^{\mathrm{b}}$ & $13.88 \pm 4.24^{\mathrm{b}}$
\end{tabular}

GI: Group I (bipartitioned); GII: Group II (non-bipartitioned); Rend.:Yield; Efic.: Efficiency. Means followed by the same letter in the same column do not differ statistically by the SNK test at $5 \%$ significance $(\mathrm{P}>0.05)$.

to produce spermatic cells (Mies Filho 1987, Almeida et al. 2010), but as there was no statistical difference among the two groups, the biometric data could not be considered as the ideal parameter to analyze the influence of the scrotal bipartition on spermatogenesis in the sheep in the present study. Therefore the quantitative histological analysis was the fundamental factor for comparison between the two groups.

Data regarding the histological parameters for assessing spermatogenesis were significantly different for the meiotic, spermatogenic and Sertoli cell yields, while only the mitotic yield was not statistically different among the bipartitioned and none bipartitioned animals (Table 2).

The mitotic yield presented very similar results between the two groups of animals studied, that means that during the phase when the spermatogonia go through continuous mitotic divisions, generating stock $\mathrm{T}$ cells, in addition to cells that will continue the differentiation process (Russell et al. 1990), the number of cells generated was similar in animals with and without scrotal bipartition. This result in numbers was similar to that found both in goats with more or less than $50 \%$ scrotal bipartition (Machado Júnior et al. 2012), but differed qualitatively because higher yield was observed in the goats with scrotal bipartition greater than 50\% compared to those with less accentuated scrotal bipartition. Qualitatively, the mitotic yields of both the groups of sheep differed from the mean found in a study with Santa Ines sheep (Martins 2006) and in Nelore breed cattle (Ferraz \& Costa 2009), that presented values higher than those of the animals in the present study.

Significant statistical difference in the meiotic yield analysis was observed between GI and GII (Table 2), a difference also observed in goats with scrotal bipartition greater than $50 \%$, compared to animals that presented scrotal bipartition less than 50\% (Machado Júnior et al. 2012). This suggests that the benefits of scrotal bipartition in the annals of the present study started with the meiotic process, in which the genetic material of the spermatocytesis duplicated and recombined (Hafez \& Hafez 2004).

The group of bipartitioned sheep (GI) presented a mean general spermatogenesis yield greater than that of the GII animals (Table 2), suggesting that the spermatogenesis process is more efficient in the sheep with scrotal bipartition, because the result indicated that more rounded spermatids were generated from the spermatogonia at the start of the seminiferous epithelium cycle. This superiority was observed in the literature only in goats with scrotal bipartition greater than $50 \%$ of the testicle length, and did not differ statistically among goats with and without scrotal bipartition of up to $50 \%$ (Machado Júnior et al. 2012). The mean yield of GI was compatible with that observed in studies that used sheep (Martins 2006), and in bulls (Ferraz \& Costa 2009), but differed from the findings by Machado Júnior et al. 2012 who used goats, so that it was greater than the yields of goats with various scrotal conformations.

The sheep in the GI presented greater Sertoli cell efficiency than the sheep in GII (Table 2), also as observed in bipartitioned goats (regardless of the degree of scrotal bipartition) when compared to goats without scrotal bipartition (Machado Júnior et al. 2012). The Sertoli cell mean in GI was greater when compared to the findings in a study on sheep (Martins 2006), but lower than that observed in cattle (Ferraz \& Costa 2009).

Studies have shown that the number of Sertoli cells per testicle is the main factor in determining sperm production and testicle size. This information is based on the fact that the Sertoli cells have a fixed support capacity for the germinative cells, so that the number of generators cells, especially the spermatids, supported by a single Sertoli cell, is the best indication of the testicle functional efficiency and consequently of the sperm production (Rocha, Debeljuk \& França 1999), that demonstrates that the Sertoli cells of the bipartitioned sheep support a greater quantity of cells of the spermatogenic line, that implies a greater quantity of spermatozoa generated in each cycle of the seminiferous epithelium.

The differences observed between the two groups in the spermatogenesis yield may have occurred due to the different spermatogenetic line process in the bipartitioned animals, because in these animals, there may be less cell apoptosis because their testes have a greater evaporation surface, favoring the testicle heat regulation process $(\mathrm{Nu}-$ nes et al. 1983, Machado Júnior et al. 2009).

\section{CONCLUSION}

It was concluded that the spermatogenetic line parameters of sheep with scrotal bipartition were different compared to those without scrotal bipartition, with greater efficiencies in spermatogenesis yield and Sertoli cells in the sheep with scrotal bipartition, suggesting that these animals present, as reported in goats, better reproductive indices. However, further research should be carried out to better assess the reproductive parameters of sheep with different scrotal characteristics.

Acknowledgements.- This study was carried out with support from CNPq (National Council for Scientific and Technological Development, Brazil)in the form of a grant from the scientific initiation program (PIBIC).

\section{REFERENCES}

Abercrombie M. 1946. Estimation of nuclear population from microtome sections. Anat. Rec. 92:239-247.

Almeida M.M., Carvalho M.A.M., Machado Júnior A.A.N., Righi D.A., Xavier F.G., Conde J., Conde Júnior A.M. \& Bombonato P.P. 2008. Efeito do grau de bipartição escrotal sobre a vascularização arterial do escroto de caprinos nativos do Estado do Piauí. Braz. J. Vet. Res. Anim. Sci. 45:167-173. 
Almeida M.M., Machado Júnior A.A.N., Ambrósio C.E., Menezes D.J.A., Righi D.A., Nascimento I.M.R. \& Carvalho M.A.M. 2010. Influência do grau de bipartição escrotal sobre parâmetros reprodutivos de caprinos. Pesq. Vet. Bras. 30:345-350.

Almeida M.M. 2003. Vascularização arterial testicular e escrotal de caprinos nativos do Estado do Piauí, segundo grau de divisão do escroto, e a relação com parâmetros reprodutivos. MSc. Dissertation, Universidade Federal do Piauí, Teresina, PI.

Amann R.P.A. \& Almquist J.O. 1962. Reproductive capacity of dairy bull. VIII. Direct and indirect measurement of testicular sperm production. J. Dairy Sci. 45:774-781.

Bittencourt R.F., Ribeiro Filho A.L. \& Almeida A.K. 2003. Avaliação de carneiros da raça Santa Inês baseando-se na circunferência escrotal. Revta Bras. Reprod. Anim. 27:195-197.

Cardoso F.M. 1981. Morfologia, cinética e quantificação da espermatogênese em zebus (Bos indicus). PhD Thesis, Universidade Federal de Minas Gerais, Belo Horizonte, MG.

Castro A.C.S., Bernedson W.E. \& Cardoso F.M. 1997. Cinética e quantificação da espermatogênese: bases morfológicas e suas aplicações em estudos da reprodução de mamíferos. Revta Bras. Reprod. Anim. 21:25-34.

Da Luz PA., Santos P.R., Andrighetto C., Jorge A.M. \& De Assis Neto A.C. 2013. The correlation between age, body weight and testicular parameters in Murrah buffalo bulls raised in Brazil. J. Reprod. Dev. 59(1):14-17.

Ferraz D.C. \& Costa D.S. 2009. Rendimento intrínseco da espermatogênese de touros Nelore sexualmente maduros. II Mostra Científica da Faculdade de Medicina Veterinária e Zootecnia, Campo Grande, MS. Available from <http://www.propp.ufms.br/gestor/titan.php?target=openFile\&fileId=541> Citedd on July 23, 2013.

Hafez B. \& Hafez E.S.E. 2004. Reprodução Animal. 7ạ ed. Manole, São Paulo.

Leal M.C. 2004. Análise morfométrica e funcional do testículo e eficiência espermatogênica em Sagüis Callithrix penicillata (Primates: Callitrichidae). MSc. Dissertation, Universidade Federal de Minas Gerais, Belo Hopizonte, MG.

Linhares S. \& Gewandsznajder F. 2000. Biologia Hoje. Ática, São Paulo.

Machado Júnior A.A.N., Miglino M.A., Menezes D.J.A., Assis Neto A.C., Leiser R., Silva R.A.B. \& Carvalho M.A.M. 2009. Influence of the bipartite scrotum on the testicular and scrotal temperatures in goats. Pesq. Vet. Bras. 29:797-802.

Machado Júnior A.A.N., Oliveira L.S., Assis Neto A.C., Alves F.R., Miglino M.A. \& Carvalho M.A.M. 2012. Spermatogenesis in goats with and without scrotum bipartition. Anim. Reprod. Sci. 130(1):42-50.

Martins J.A.M. 2006. Avaliação da biometria testicular, epididimal e das glândulas sexuais acessórias e correlações entre características biométricas e histológicas em carneiros deslanados sem padrão racial definido (SPRD). MSc. Dissertation, Universidade Federal do Ceará, Fortaleza, CE.

Melo T.M.V., Lima Filho J.A.C., Silva J.G., Amaral C.R.A., Correia F.R., Sampaio M.O., Souza W.M.A. \& Coelho M.C.O.C. 2013. Bipartição escrotal associa- da à má formação prepucial em ovino Morada Nova: relato de caso. Arq. Bras. Med. Vet. Zootec. 65:1103-1106.

Mies Filho A. 1987. Reprodução dos animais e inseminação artificial. 4⿳亠丷a ed. Livraria Sulina, Porto Alegre.

Nunes A.S. 2005. Morfologia do funículo espermático e dos escrotos em caprinos nativos do Estado do Piauí, com diferentes configurações escrotais. MSc. Dissertation, Universidade Federal do Piauí, Terezina, PI.

Nunes J.F., Riera G.S., Silva A.E.F.D., Ponce De Leon F.A. \& Lima F.A.M. 1983. Características espermáticas de caprinos Moxotó de acordo com a morfologia escrotal. Report no.6, Embrapa Caprinos, Sobral, CE.

Oliveira L.H. \& Menezes A.J.A. 2012. Características morfológicas do funículo espermático em ovinos sem raça definida, oriundos do estado da Paraíba, com diferentes graus de bipartição escrotal. Anais VIII Congresso de Iniciação Científica da Universidade Federal de Campina Grande, Patos. Available from <http://pesquisa.ufcg.edu.br/anais/2012/arquivos/resumofinal2-laura-pivic_888.pdf> Cited on July 30, 2013.

Oliveira R.R., Pinheiro Júnior J.W., Câmara D.R., Ribeiro K.L.C., Santos R.M.B., Guerra M.M.P. \& Bonelli M. 2002. Aspectos morfométricos e irrigação arterial do escroto e testículo em caprinos nativos do estado de Pernambuco. Revta Bras. Reprod. Anim. 26:129-131.

Ortavante R., Courot M. \& Hochereau-de-Reviers M.T. 1984. Espermatogénesis em los mamíferos domésticos. In: Cole H.H. \& Cupps P.T. (Eds), Reproduccion de los animales domésticos. $3^{\underline{a}}$ ed. Acribia, Zaragoza.

Robertshaw D. 1982. Concepts in animal adaptation: thermorregulation of the goat. Dairy Goat J. 3:395-397.

Rocha D.C.M., Debeljuk L. \& França L.R. 1999. Exposure to Constant ligth during testis development increase daily sperm production in adult Wistar rats. Tissue Cell 31:372-379.

Russell L.D., Ettlin R.A., Sinha-Hikin A.P. \& Clegg E.D. 1990. Histological and histopathological evaluation of the testis. Cache River Press, Clearwater.

Santos D.O., Simplício A.A. \& Machado R. 1998. Características escrototesticulares e do ejaculado em bodes mestiços submetidos à insulação escrotal. Arq. Bras. Med. Vet. Zootec. 50:287-291.

Siddiqui H.U.R., Ahmad A.A. \& Han Z.K. 2005. Biometrical studies of testes of the ram. J. Agricult. Social Sci. 1:78-79.

Silva J.V., Ribeiro M.N., Silva L.P.G., Pimenta Filho E.C. \& Vilar Filho A.C. 2001. Cronologia de caprinos mestiços e naturalizados criados no semiárido paraibano. Agropec. Téc. 22:45-51.

Tolentino M.L.D.L. \& Sousa O.B. 2012. Descrição histológica do escroto de ovinos nativos do estado da Paraíba, segundo o grau de bipartição escrotal e sua relação com a biometria testicular. Anais VIII Congresso de Iniciação Científica da Universidade Federal de Campina Grande, Patos, PB. Available from: <http://pesquisa.ufcg.edu.br/anais/2012/arquivos/619.pdf> Cited on July 30, 1913.

Vilar Filho A.C., Birgel E.H., Barnabe V.H., Visintin J.A. \& Barnabe R.C. 1993. Características testiculares e seminais de caprinos criados na região semi-árida do Estado da Paraíba. Revta Bras. Reprod. Anim. 17:17-22. 